\title{
Santri dan Nasionalisme
}

\author{
${ }^{*}$ Iffan Ahmad Gufron \\ ${ }^{1}$ Institut Agama Islam Bunga Bangsa
}

\begin{abstract}
This Paper Clarifies the close connection between santri and nationalism. Asking the nationalism of santri it means forgetting the history of NKRI (Unitarian State of Indonesia). The history book of indonesia from colonial era or pre-independence era, independence era to post-independence era told the big contribution of santri in all era. Pesantren as the genuine institution of islamic education in indonesia which creates santri was built for educating indonesian resources. So, nationalism for santri as graduate of pesantren is contributes in various filelds of life in Indonesia.
\end{abstract}

Key Word: Santri, Nasionalism, Indonesia

\section{Pendahuluan}

Pasca runtuhnya gedung world Trade Center (WTC) di Amerika Serikat stigma negatif terhadap Islam muncul bahkan menjadi semacam islamofobia di Amerika dan negara-negara Eropa. Islam dikesan kan sebagai agama teroris atau minimalnya mentolelir perbuatan terorisme. Impact islamofobia tidak hanya marak di negara-negara Barat, namun juga ke seantero dunia termasuk ke Indonesia yang notabene negara Muslim terbesar di dunia. Lembaga-lembaga Islam seperti pesantren dicurigai sebagai tempat kaderisasi radikalisme dan terorisme dan para santri dicurigai sebagai radikal dan teroris. Stigma seperti itu sangat merugikan pesantren dan para santri, seakan-akan pesantren dan kalangan pesantren di dalamnya termasuk para santri tidak didik nasionalisme atau cinta tanah air, padahal, kalau kita napak tilas sejarah Indonesia merdeka, banyak sekali peran besar santri dalam mewujudkan Indonesia merdeka dan berkontribusi dalam mengisi kemerdekaan.

Istilah santri sendiri sempat menjadi pembicaraan tahun 1960-an sejak diterbitkannya sebuah hasil penelitian seorang antropolog asal Amerika serikat bernama Clifford Geertz di sebuah daerah bernama Pare di kabupaten kediri yang kemudian diberi judul The religion of Java. Penelitian yang kemudian menjadi karya master piece-nya berlangsung selama kurang lebih 1 tahun 4 bulan ini telah mengkategorisasi masyarakat "jawa" menjadi santri, abangan dan priyayi. Istilah santri dalam karya Geertz lebih menitik beratkan pada penggolongan masyarakat jawa menurut tingkat ketaatan menjalankan ajaran ibadah agama Islam (Suparlan, 1981: IX), padahal menurut Zamakhsyari Dhofier dalam"Tradisi Pesantren", santri adalah murid yang mengikuti pelajaran di Pesantren (Dhofier, 1982: 51-52) yang artinya santri merupakan salah satu elemen terpenting pesantren sehingga besar kecilnya sebuah pesantren salah satunya ditentukan dari banyak sedikitnya santri yang belajar di pesantren tersebut. Lebih jauh Ahmad Basso menerangkan bahwa santri atau menjadi santri (dados santri) melampau pengertian nyantri di sebuah pesantren yatu orang-orang yang mencari ilmu di pesantren atau juga yang mengamalkan dengan baik ajaran agama Islam sebagaimana dijelaskan 
Zamakhsyari Dhofier dan Geertz, namun identitas santri melekat seumur hidup artinya menjadi santri adalah juga berarti proses pembelajaran dan pengajaran yang tidak pernah berhenti seumur hidup (Baso, 2012: 87-88).

Diluar stigma negatif akibat stigma konspirasi global terhadap pesantren, perjalanan sejarah Indonesia tidak bisa dilepaskan dari peran dan kontribusi pesantren beserta para santri baik dalam masa pra kemerdekan, masa kemerdekaan maupun pasca kemerdekaan. Peran signifikan para santri untuk Indonesia kemudian diapresiasi oleh Presiden Jokowi dengan mengeluarkan Keputusan Presiden Nomor 22 Tahun 2015 mengenai penetapan tanggal 22 Oktober sebagai hari santri Nasional. Tanggal itu merujuk pada resolusi Jihad yang diserukan KH. Hasyim Asy'ari kepada para santri untuk berjuang demi tanah air.

\section{Pengertian Santri Nasionalisme}

dan

Nurcholish Madjid menyebut dua pendapat tentang asal usul kata santri. Pertama, kata santri berasal dari kata "shastri" dalam bahasa sanskerta yang artinya melek huruf. C.C.Berg mengartikan shastri dengan orang yang tahu buku-buku suci Agama Hindu. Pendapat ini merujuk kepada para santri yang berusaha mendalami agama melalui kitab-kitab bertulisan Arab asli maupun arab pegon. Kedua, kata santri berasal dari kata "cantrik" dalam bahasa Jawa berarti seseorang yang selalu mengikuti seorang guru kemana guru ini pergi menetap. Pengamat lain, A. H. John berpendapat bahwa santri berasal dari bahasa Tamil yang berarti guru mengaji (Dhofier, 1982: 18). Dengan demikian, dari pendapat-pendapat tersebut dapat disimpulkan bahwa santri adalah seseorang yang mendalami agama melalui kitab-kitab dengan mengikuti guru atau kyai.

Nasionalisme menjadi Istilah yang baru digunakan di akhir abad ke delapan belas atau awal abad kesembilan belas. Penggunaan istilah ini awalnya di dalam Bahasa Inggris pada tahun 1836 bersifat teologis yaitu sebagi doktrin bahwa bangsa-bangsa tertentu dipilih secara ilahiah. Sejak itu, istilah ini disamakan dengan egoisme nasional. Istilah nasionalisme pada akhir-akhir ini digunakan untuk beberapa hal (Smith, 2001: 6-7) suatu proses pembentukan atau pertumbuhan bangsa-bangsa; 2) suatu sentimen atau kesadaran memiliki bangsa bersangkutan; 3) suatu bahasa dan simbolisme bangsa; 4) suatu gerakan sosial dan politik demi bangsa bersangkutan; 5) suatu doktrin atau ideologi bangsa baik yang umum maupun yang khusus.

Hasan Al-Banna lebih lanjut
mengatakan
berkaitan
nasionalisme (Suhawi, 2009 396):

"Jika yang dimaksud dengan nasionalisme oleh para penyerunya adalah cinta tanah air, keberpihakan padanya dan kerinduan yang terus menggebu terhadapnya, maka hal itu sebenarnya sudah tertanam dalam fitrah manusia. Lebih dari itu, Islam telah menganjurkan yang demikian.....jika yang mereka maksudkan dengan nasionalisme adalah keharusan berjuang membebaskan tanah air dari cengkeraman imperialisme, menanamkan makna kehormatan dan kebebasan dalam jiwa putra-putri bangsa, maka kami pun sepakat tentang itu.....jika yang mereka maksudkan dengan nasionalisme adalah memperkuat ikatan kekeluargaan antara anggota masyarakat atau warga negara serta menunjukkan kepada mereka cara-cara memanfaatkan ikatan itu untuk mencapai kepentingan bersama, maka disini pun kami sepakat dengan mereka....jika yang mereka maksudkan dengan nasionalisme adalah membebaskan negeri-negeri lain dan menguasai dunia, maka itu pun telah 
diwajibkan oleh Islam. islam bahkan mengarahkan para pasukan pembebas untuk melakukan pembebasan yang paling berbekas......jika yang dimaksud dengan kebangsaan oleh para tokohnya adalah generasi penerus harus mengikuti jejak para pendahulunya dalam mencapai kejayaan, kebesaran dan kecemerlangan; dan bahwa generasi penerus harus menjadikan para pendahulunya sebagai panutan; dan bahwa kebesaran sang ayah merupakan kebanggaan bagi anaknya, yang selalu mendorongnya untuk mengikuti jejak sang ayah karena hubungan darah; maka disini kami pun sejalan dengan mereka."

Pendapat Hasan Al-Banna diatas, menjelaskan secara gamblang bahwa ide nasionalisme dan Islam itu tidak bertentangan. Pertanyaaanya kemudian Bagaimana mungkin para santri sebagai para pembelajar Islam tidak punya rasa nasionalisme?

\section{Nasionalisme Santri di Masa Pra kemerdekaan}

Pesantren adalah lembaga pendidikan yang khas atau genuin dari Indonesia (Nusantara), jumlahnya tersebar di seluruh nusantara dan mayoritas berdiri sebelum Proklamasi Kemerdekaan Indonesia. Pendirian pesantren di masa lalu didorong untuk mencerdaskan anak bangsa supaya punya kekuatan untuk keluar dari kolonialisme. Para santri di masa pra kemerdekaan dididik untuk anti kolonialisme, konon salah satu penyebab kebanyakan pesantren tidak mengajarkan Bahasa Penjajah (Inggris, Portugis, Belanda dan Jepang) dan ilmu umum adalah berdasarkan strategi anti kolonialisme dengan berpegang pada kaidah "man tasyabbaha bi qoumin fabuwa minbum" (barang siapa menyerupai suatu kaum maka ia termasuk dalam golongannya), sebagai bangsa yang anti kolonialisme, maka apa saja yang berbau kolonialis, seperti bahasa, cara berpakaian, budaya, ilmu dan sebagainya harus dihindari, maka kemudain muncul slogan-slogan seperti bahasa kafir, budaya kafir dan sebagainya.

Beberapa pesantren justru melakukan strategi yang berbeda semisal Pondok Modern Gontor yang justru mengajarkan bahasa penjajah (Inggris), memakai celana dalam pembelajaran dan kelas-kelas yang menggunakan bangku dan meja sebagaimana sekolah-sekolah yang didirikan kaum penjajah. Dalam suatu naskah Buton, Sulawesi Tenggara ditemukan naskah-naskah berbahasa Melayu dan Belanda dengan huruf Arab pegon (Baso, 2012: 40-41). Para santri mengamalkan dan menguasai bahasa penjajah (Eropa) bukan untuk dikomunikasikan dan dipakai dalam tulismenulis, akan tetapi dipakai sebagai jalan menuju kepada dunia pengetahuan dan peradaban orang-orang Eropa, selain juga ingin mempelajari ideologi-ideologi sekuler, lalu dilihat relevansinya dengan semangat kebangsaan mereka, setelah itu mereke mengukuhkan karakter berbangsa dan juga dekolonisasi sebagai bukti nasionalisme dan cinta tanah air.

\section{Nasionalisme Santri di Masa Kemerdekaan}

Masa kemerdekaan adalah masamasa para santri berperan baik dalam jalur diplomasi politik dan diplomasi maupun militer. Pada jalur Politik, tokoh tokoh pergerakan tergolong kaum santri seperti K.H. Abdul Wahid Hasyim, Ki Bagus Hadikusumo, Mr. Mohamad Roem, Abukusno Tjokrosujoso (Adik H.O.S. Cokroaminoto), H. Agus Salim dan lainsebagainya beberapa juga tergabung dalam anggota BPUPKI.

Di bidang militer lahir lasykar Pembela Tanah Air pada bulan November 1943 lalu diikuti oleh kelahiran lasykar Hizbullah beberapa 
minggu kemudian (Zuhri, 1987: 221222). Kedua badan kelasykaran ini meskipun dibentuk awalnya untuk membantu Jepang, namun kedua badan kelasykaran tersebut menjadi cikal bakal $\mathrm{BKR} / \mathrm{TKR}$ yang merupakan institusi militer pertama di republik Indonesia dan yang menjadi persamaan kedua badan kelasykaran tersebut adalah keterlibatan kaum santri di dalamnya.

$\begin{array}{lll}\text { Keterlibatan } & \text { kaum } & \text { santri } \\ \text { berikutnya } & \text { adalah } & \text { dalam }\end{array}$
mempertahankan kemerdekaan. Resolusi Jihad yang dicetuskan oleh K.H. Hasyim Asy'ari adalah bentuk keterlibatan nyata para santri dalam menjaga dan mepertahankan tanah airnya dari penjajah yang ingin kembali menguasai Indonesia dengan jargonnya "bubbul wathoni minal iman", makanya wajar kalau kemudian Presiden Joko Widodo menetapkan waktu pencetusan Resolusi Jihad menjadi Hari Santri Nasional.

\section{Nasionalisme Santri di Masa Pasca Kemerdekaan}

Keterlibatan pesantren bersama para santrinya dapat diamati melalui proses pendidikan di Pesantren maupun output lulusan pesantren dalam kiprahnya di masyarakat. Setiap santri dituntut belajar sepanjang hayat baik saat di Pesantren maupun setelah keluar dari pesantren. Tuntutan itu menjadikan para santri menjadi pembelajar dalam hidupnya dan masyarakatnya. Masyarakat adalah ujian sebenarnya dari kualitas seorang santri, santri berasal dari masyarakat dan akan kembali ke masyarakat.

Kiai Saifuddin Zuhri menulis dalam bukunya Guruku orang-orang dari pesantren, sebagai berikut (Zuhri, 1982:78:
Para santri adalah anak-anak rakyat, amat paham tentang arti kata rakyat, paham benar tentang kebudayaan rakyat, tentang keseniannya, agamanya, jalan pikirannya, cara hidupnya, semangat dan cita-citanya, suka dukanya, tentang nasibnya, dan segala liku-liku hidup rakyatnya, santri lahir dari sana, demikian mereka hidup dan lalu mati pun di sana pula. Sebab itu, para santri dan kiai sangat paham tentang arti hidup dalam penjajahan."

K.H. Imam Zarkasyi, salah satu Trimurti (pendiri) Pondok Modern Gontor pernah mengatakan kepada para santri-santrinya, kesuksesan para santri adalah ketika ia mampu membangun kampungnya (menjadi Kiai kampung). Penulis kira inilah bentuk nasionalisme kaum santri yang sebenarnya ketika ia kembali ke kampung halamannya dan membangun kampungnya. Dimanapun ia berada ia bisa bermanfaat bagi keluaraga, masyarakat nusa bangsa dan agama.

\section{Penutup}

Peran dan kontribusi pesantren dalam membangun dan mempertahankan tanah airnya, negaranya tidak dapat lagi dipertanyakan. Kehadirannya dalam setiap peristiwa perjalanan bangssa Indonesia baik dari masa pra kemerdekaan, masa kemerdekaan maupun pada masa pasca kemerdekaan menjadi bukti otentik dari keterlibatan kaum dalam membangun bangsa ini. Keberadaan dan keterlibatan dalam setiap bidang baik politik, ekonomi, pendidikan, militer dan sebagainya menjadikannya nasionalis sejati yang cinta pada tanah airnya. 


\section{Referensi}

Baso, Ahmad. Islam Pascakolonial: Perselingkuban Agama, Kolonialisme dan Liberalisme. Bandung: Mizan, 2005. - Pesantren Studies $2 a$. Jakarta: Pustaka Afid, 2012. - Pesantren Studies $2 b$. Jakarta: Pustaka Afid, 2012. - Pesantren Studies $4 a$. Jakarta: Pustaka Afid, 2013.

Dhofier, Zamakhsari Dhofier, Tradisi Pesantren: Studi tentang pandangan Kyai. Jakarta: LP3ES, 1994.

Kohn, Hans. Nasionalisme, Arti dan Sejarahnya. Jakarta: Erlangga, 1984.

Ihsan, Nur Hadi. Pola Penyelenggaraan Pondok Pesantren Modern: Profil Pondoke Modern Darussalam Gontor. Jakarta: Direktorat Pendidikan Keagamaan dan Pondok Pesantren, DEPAG RI, 2001.

Smith, Anthony D. Nasionalisme: Teori, Ideologi, Sejarah. Jakarta: Erlangga, 2003

Steenbrink, Karel A.. Pesantren Madrasah Sekolah: Pendidikan Islam dalan kurun Modern. Jakarta: LP3ES, 1986.

Suhawi, Achmad. Gymnastik Politik Nasionalis Radikal b.
Wiryosukarto, Amir Hamzah dkk.. Biografi K.H. Imam Zarkasyi: Dari Gontor Merintis Pondok Modern. Ponorogo: Gontor Press, 1996. Zuhri, Saifuddin. Berangkat dari pesantren. Jakarta: Gunung Agung, 1982. 